\title{
THE ANDES MOUNTAIN RANGE UPLIFT AS A VICARIANT EVENT IN THE PIMELIINAE (COLEOPTERA: TENEBRIONIDAE) IN SOUTHERN SOUTH AMERICA
}

\author{
Gustvao E. Flores ${ }^{1} \&$ Jaime Pizarro-Araya ${ }^{2}$
}

\begin{abstract}
The Andes mountain range extends over $8500 \mathrm{~km}$ along the Pacific coast of South America. Its medium altitude is $3500 \mathrm{~m}$, reaching more than $6000 \mathrm{~m}$ at different latitudes. The uplift of the Andes split arid habitats creating very diverse ecosystems on both sides. The distribution of the Pimeliinae (Coleoptera: Tenebrionidae) south of parallel $15^{\circ}$ South is analysed, where the Andean mountain range separates xeric habitats both eastward and westward. The genera of Pimeliinae show four distribution patterns: endemic taxa east of the Andes, endemic taxa west of the Andes, taxa widely distributed on both sides of the Andes, and taxa inhabiting high altitudes in the Andes. Known phylogenies of genera and species of Pimeliinae are examined in terms of the Andean mountain uplift creating a vicariant event. A biogeographical track exhibited by certain genera of Pimeliinae connecting central Chile and southern Argentina is examined.
\end{abstract}

Keywords : South America, Andes mountain range uplift, distribution patterns, Tenebrionidae, Pimeliinae, vicariance.

\section{RÉSUMÉ}

La vaste étendue des Andes couvre plus que $8500 \mathrm{~km}$ le long de la côte pacifique de l'Amérique du sud. L'altitude moyenne est de $3500 \mathrm{~m}$ mais elle dépasse plus que $6000 \mathrm{~m}$ avec des écosystemes très variés des deux côtés. La distribution des Pimeliinae (Coleoptera : Tenebrionidae) est examinée au sud du $15^{\mathrm{eme}}$ parallèlle où la formation des Andes a séparé des habitats désertiques à la fois vers l'est et vers l'ouest. Les genres de Pimeliinae montrent quatre modèles de distribution : espèces endémiques à l'ouest des Andes ; espèces endémiques à l'est des Andes; espèces largement répandues les deux côtés des Andes et espèces habitant les hautes altitudes des Andes. La phylogénie connue de certaines espèces et genres est examinée pour événement vicariant à la suite de la formation des montagnes andines. Un chemin biogeographique démontré par quelques genres de Pimeliinae liant le Chile central et l'Argentine du sud est analysé.

Mots-clés : Amérique du sud, formation des Andes, modèles de distribution, Tenebrionidae, Pimeliinae, vicariance.

\section{INTRODUCTION}

The Andes mountain range extends over $8500 \mathrm{~km}$ along the Pacific coast of South America from Venezuela down south to Tierra del Fuego. Its medium altitude is $3500 \mathrm{~m}$, reaching more than 6000 $\mathrm{m}$ at different latitudes and splitting very diverse ecosystems on both sides. South of parallel $15^{\circ}$ South the Andean mountain range separates xeric habitats both eastward (due to the Humboldt current) and westward (due to the Andean mountain range, which acts as an orographic barrier to the winds of the Pacific Ocean) (HARTLEY, 2003). This area is named the "arid corredor of southern South America".
Pimeliinae (Coleoptera: Tenebrionidae), are rich in number of species in this xeric area: many being apterous, and restricted in distribution. These are of particular interest in biogeographic studies (RoIG JuÑENT \& Flores, 2001, RoIg JuÑENT et al., 2003, Pizarro Araya \& Jerez, 2004).

The objectives of this study are to analyse the distributional patterns of the Pimeliinae in southern South America in relation to the Andean mountain range and to examine if the uplift of these mountains created a vicariant event for elements of the pimeliine fauna.

\footnotetext{
'Laboratorio de Entomología, Instituto Argentino de Investigaciones de las Zonas Áridas (IADIZA, CRICYT), Casilla de correo 507, 5500 Mendoza, Argentina (e-mail: gflores@lab.cricyt.edu.ar)

${ }^{2}$ Laboratorio de Entomología Ecológica, Departamento de Biología, Facultad de Ciencias, Universidad de La Serena, Casilla 599, La Serena, Chile (e-mail: jaimepizarro@udec.cl)
}

Cahiers scientifiques - Département du Rhône - Muséum, Lyon - º 10 (2006)

p. $95-102$ 


\section{Methods}

We analyzed the distribution of 669 species of Pimeliinae belonging to 15 tribes in 74 genera and subgenera in Southern South America (Table I). The arrangement of genera in tribes follow DOYEN (1993) while the distributional data of the genera and species follow PEÑA (1966), Flores (1998), and other recent revisions. We then examine the known phylogenies of selected genera of Pimeliinae in relationship to their distribution to the Andean mountains to see if the uplift acted as a vicariant event. This uplift event is also examined in other groups of arthropods. Finally, we made a panbiogeographic approach (MORRONE \& CRISCI, 1995) using individual tracks of five genera of Pimeliinae and two genera of Carabidae distributed in central Chile and southern Argentina between parallels $37^{\circ}-41^{\circ}$ South, where the mountain range is of low altitudes.

\section{RESUlTS}

The Table I summarizes the distributional information of Pimeliinae inhabiting southern South America in relation to the Andes mountain range. Genera and subgenera of Pimeliinae exhibit four distribution patterns: taxa endemic to east of the Andes, taxa endemic to west of the Andes, taxa widely distributed on both sides of the Andes, and taxa inhabiting Andean high altitudes.

Known phylogenies of tribes and genera of Pimeliinae in South America include: 1) at generic level, the phylogeny of Nycteliini (FLores, 2000) (Fig. 1) indicating as a oval node where the uplift of the Andes split the original populations creating: the genera Epipedonota Solier and Patagonogenius Flores (east) and Callyntra Solier and Auladera Solier (west); at specific level: 2) the phylogeny of Mitragenius Solier, Auladera and Patagonogenius (FloRes, 1999) (Fig. 2 ), in which the uplift of the Andes split the original populations into two species of Mitragenius in central Chile (west) while the rest remained in central
Argentina and Patagonia; 3) the phylogeny of Platesthes Waterhouse (Praocini) (FlORES, 2004) (Fig. 3) shows one species ( $P$. vidali Peña) inhabiting central Chile (west) and the remaining species in Patagonian steppes (east); 4) the phylogeny of Discopleurus Lacordaire (Stenosini) (AALBU \& ANDREWS, 1996) (Fig. 4) in which the uplift of the Andes split the original populations into two species, D. baloghi Kaszab and D. argentinensis Aalbu \& Andrews west and east of the Andes; and 5) the phylogeny of Caenocrypticoides Kaszab (Caenocrypticini) (Flores \& Pizarro Araya, 2004) (Fig. 5) in which the uplift of the Andes also split the original populations into two species, $C$. translucidus Kaszab and C. triplehorni Flores \& Pizarro Araya west and east of the Andes. This vicariant event leaving species both east and west of the Andes originating by the uplift of the Andes is also found in the phylogeny of other groups of arthropods such as Acanthogonatus Karsch (Araneae, Mygalomorphae) (GolobofF, 1995), Tristiridae Rehn (Orthoptera, Acridoidea) (Cigliano, 1989), Barypus Dejean and Cnemalobus Guérin-Méneville (Coleoptera, Carabidae) (RoIG JUÑENT, 1995, 2002).

A panbiogeographic approach using individual tracks of five genera of Pimeliinae and two genera of Carabidae distributed in central Chile and southern Argentina between parallels $37^{\circ}-41^{\circ}$ South resulted in a generalized track connecting xeric and mesic areas in central Chile with arid Patagonian steppes in southern Argentina (Fig. 6). This track crosses the Andes between parallels $37^{\circ}-41^{\circ}$ South, where the mountain range is of low altitude $(1500-2000 \mathrm{msl})$. This track is found in genera of Pimeliinae with different dispersion capacities such as Nyctopetus Guérin-Ménéville (winged) and Platesthes Waterhouse, Peltolobus Lacordaire, Nyctelia Latreille, and Mitragenius Solier (flightless). This track has been named Patagonic by ROIG JUÑENT et al. (2003) and also show a branch connecting Patagonian steppes with high altitudes of the Precordilera mountain range in western Argentina (Fig. 6).

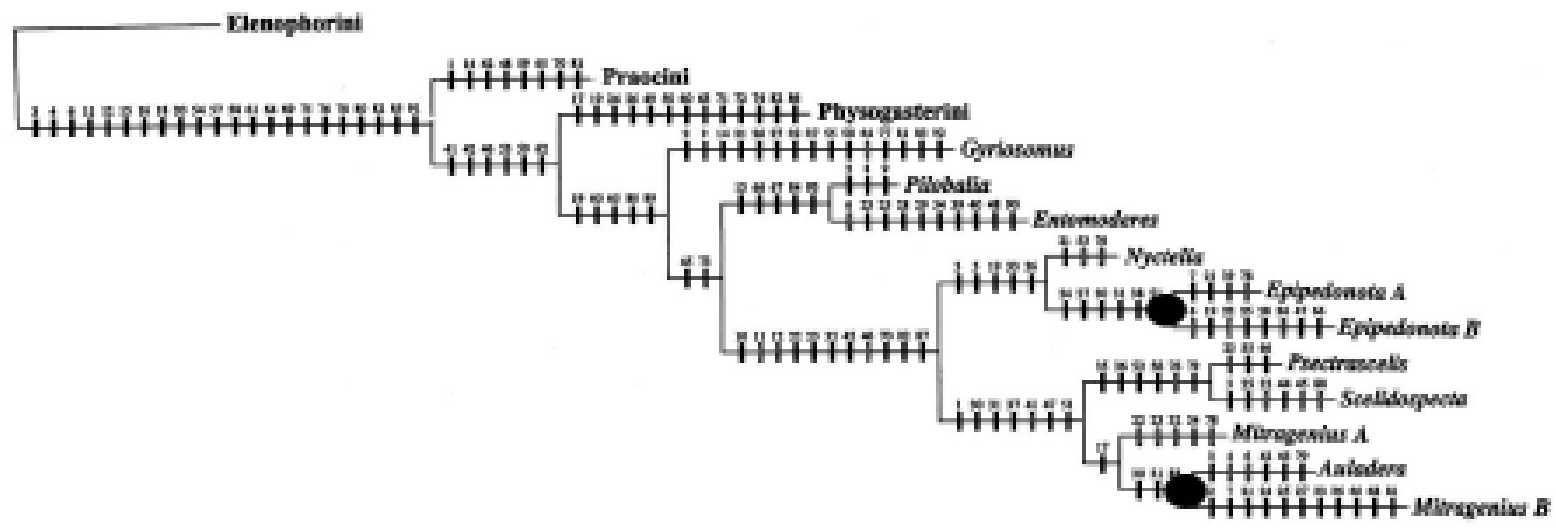

Fig. 1 - Cladogram of genera of Nycteliini (Flores, 2000). The black circle at the branch node indicates the uplift of the Andes. Epipedonota B currently includes the restored genus Callyntra and Mitragenius B currently is the genus Patagonogenius. 


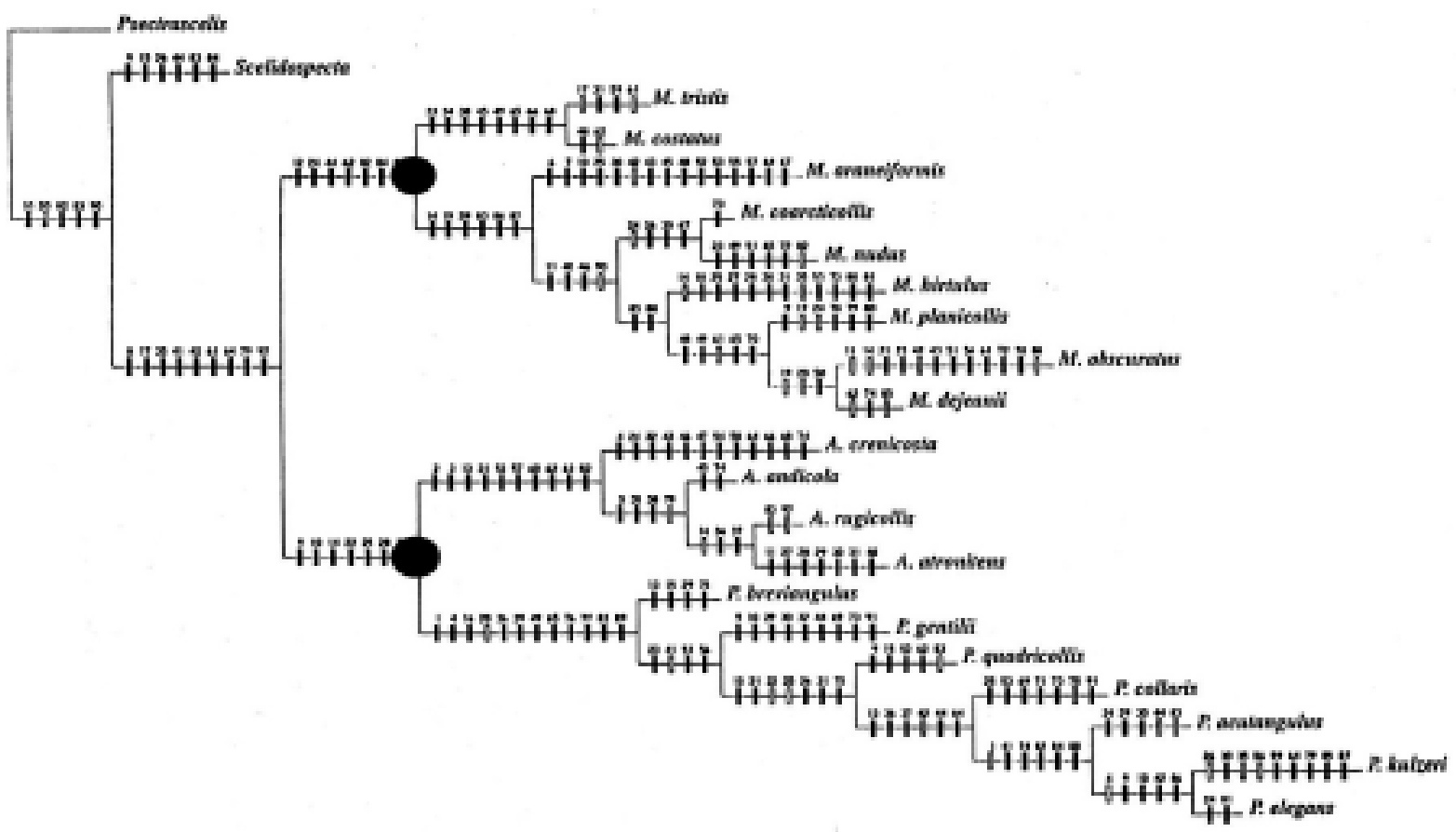

Fig. 2 - Cladogram of species of three genera of Nycteliini (Flores, 1999). The black circle at the branch node indicates the uplift of the Andes.

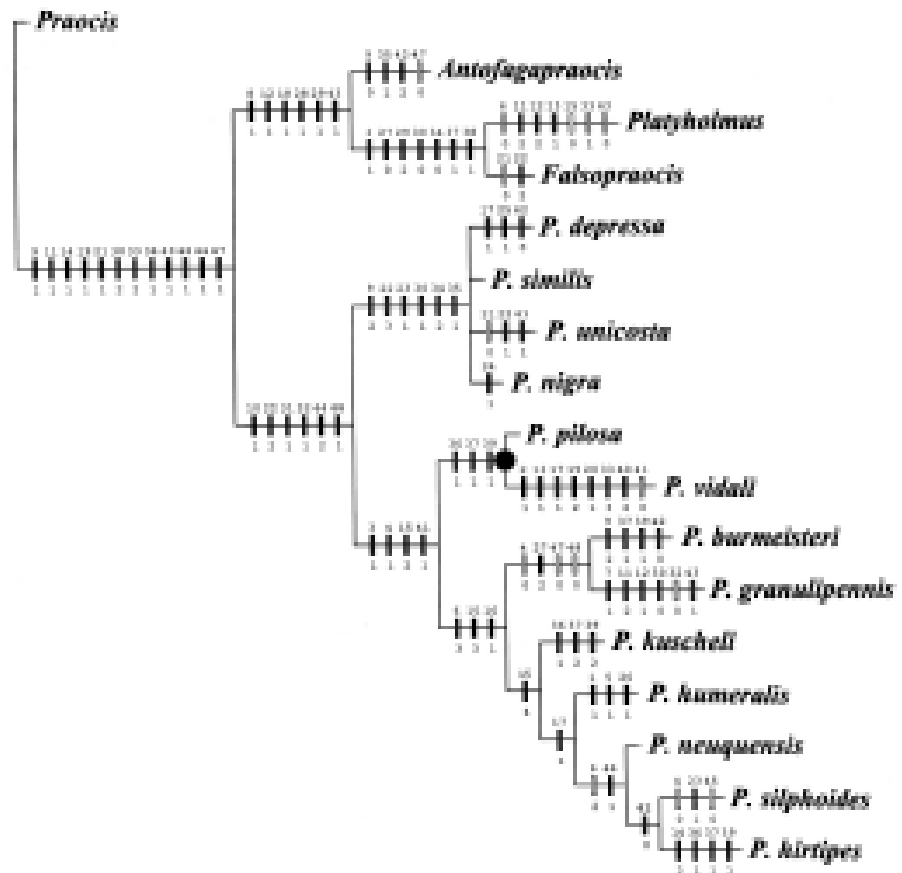

Fig. 3 - Cladogram of species of Platesthes (Flores, 2004). The black circle at the branch node indicates the uplift of the Andes. 


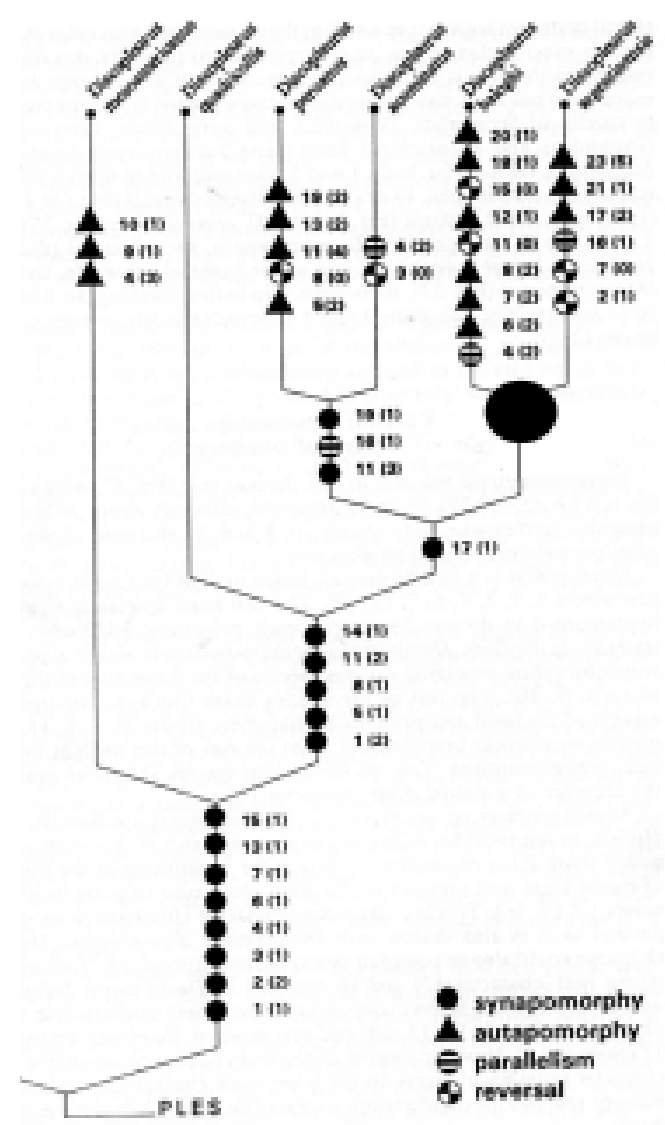

Fig. 4 - Cladogram of species of Discopleurus (Aalbu \& Andrews, 1996). The black circle at the branch node indicates the uplift of the Andes.

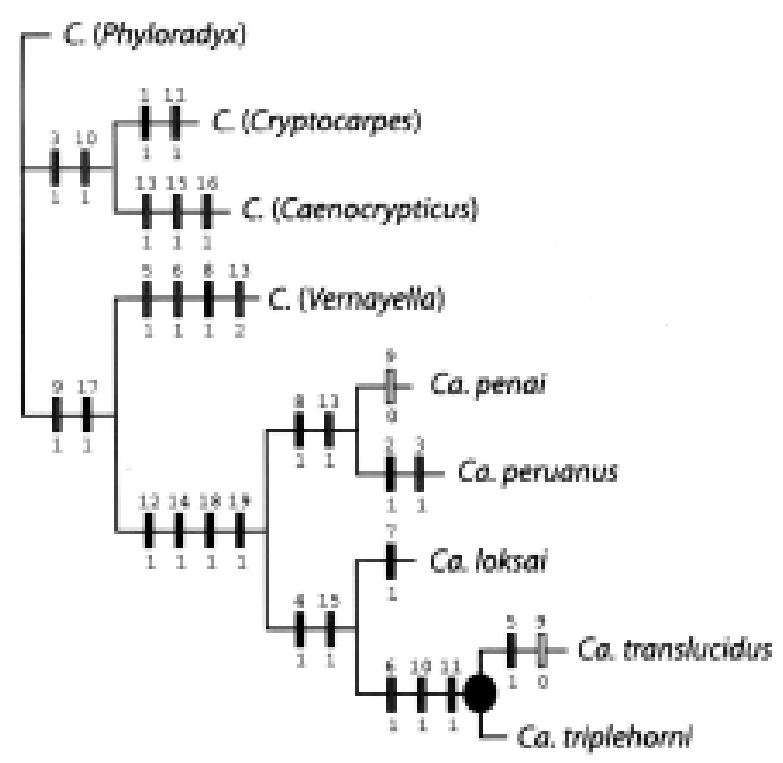

Fig. 5 - Cladogram of species of Caenocrypticoides (Flores \& Pizarro Araya, 2004). The black circle at the branch node indicates the uplift of the Andes. C.= Caenocrypticus; $\mathrm{Ca}=$ Caenocrypticoides.

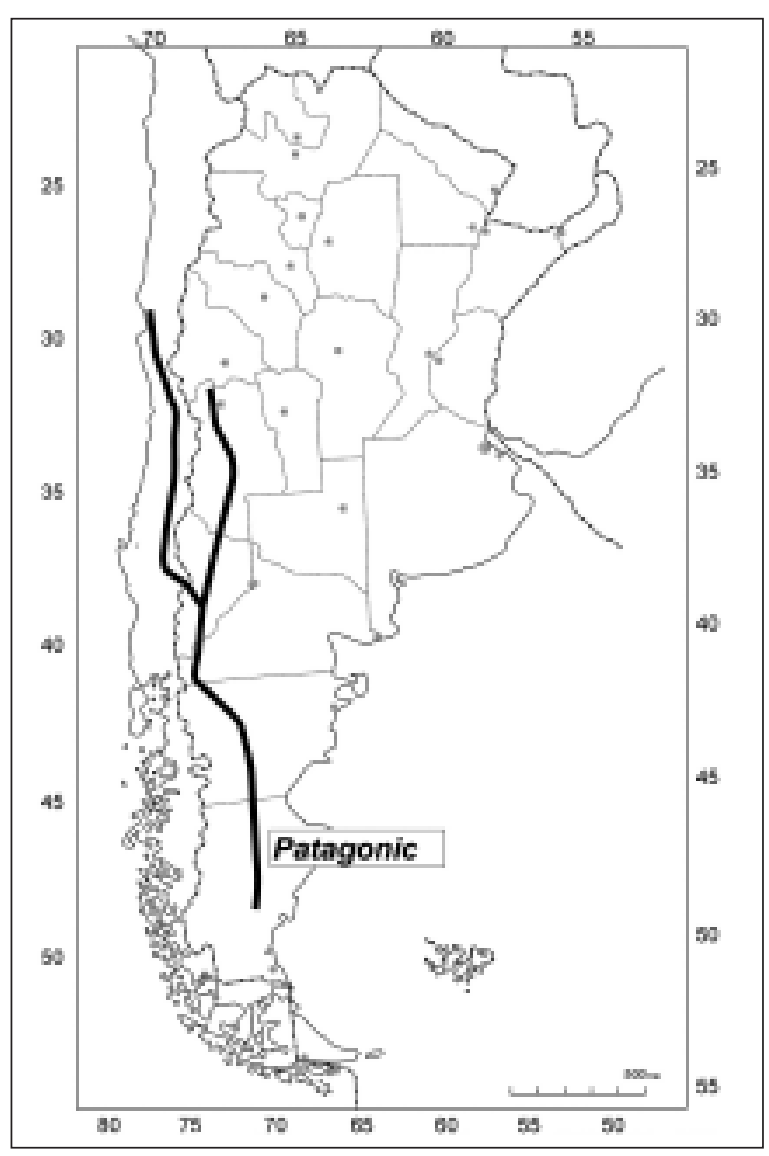

Fig. 6 - Patagonic generalized track. 


\section{Conclusions}

1) There are four distribution patterns in Pimeliinae in Southern South America in relation to the Andes mountain range: a) taxa endemic to east of the Andes, b) taxa endemic to west of the Andes, c) taxa widely distributed on both sides of the Andes, and d) taxa inhabiting high altitudes in the Andes.

2) The Andes is vicariant at different taxonomic levels: genera and species. The Andean uplift affected most of the genera and subgenera of Pimeliinae: 49 of 74 analysed are endemic to east or to west of the Andes.

3) Among the genera widely distributed east and west of the Andes (13), the Andean uplift affected most of its species (only very few species inhabit both sides of the Andes).

4) Species of genera with different capacities of dispersion (winged or flightless) show the same distribution pattern (i.e.: endemic east or west of the Andes). 5) Only three apterous genera inhabit exclusively high altitudes in the Andes (up to $3000 \mathrm{msl}$ ), suggesting that these species evolved together with the Andean uplift and became adapted to the new ecological and climatic conditions created by the uplift.

\section{REFERENCES}

AAlbu R.L. \& ANDREws F.G. (1996) - A revision of the Neotropical genus Discopleurus Lacordaire (Tenebrionidae: Stenosini). Coleopterists Bulletin 50 (1), p. 14-38.

Cigliano M.M. (1989) - A cladistic analysis of the family Tristiridae (Orthoptera, Acridoidea). Cladistics 5 (4), p. 379-393.

DoyEN J.T. (1993) - Cladistic relationships among Pimeliinae Tenebrionidae (Coleoptera). Journal of the New York Entomological Society 101 (4), p. 443-514.

Flores G.E. (1998) - Tenebrionidae, pp. 232?240. In: Morrone J.J. \& Coscarón S. (eds): Biodiversidad de artrópodos argentinos: Una perspectiva biotaxonómica. Ediciones Sur, La Plata, Argentina.

Flores G.E. (1999) - Systematic revision and cladistic analysis of the Neotropical genera Mitragenius Solier, Auladera Solier and Patagonogenius gen. n. (Coleoptera: Tenebrionidae). Entomologica Scandinavica 30 (4), p. 361-396.
6) The "Patagonic" biogeographic track connecting arid lands east and west of the Andes is reflected by five genera of Pimeliinae with different capacity of dispersion (winged or flightless) and two genera of Carabidae.

\section{Acknowledgements}

We gratefully acknowledge to the organizers of the Second International Symposium on Tenebrionid beetles (Lyon) for the invitation to write this paper, Rolf L. Aalbu for suggestions improving this paper and for the summary in French. This study was supported by the Consejo Nacional de Investigaciones Científicas y Técnicas (CONICET, Argentina), by the Fondo para la Investigación Científica y Tecnológica (FONCYT Argentina, PICT 01-11120), by a grant of the BBVA Foundation, Spain: "Diseño de una red de reservas para la protección de la biodiversidad en América del Sur Austral utilizando modelos predictivos de distribución con taxones hiperdiversos" and by a grant DIULS 220.2.17 from Dirección de Investigación, Universidad de La Serena, La Serena, Chile.

Flores G.E. (2000) - Cladistic analysis of the Neotropical tribe Nycteliini (Coleoptera: Tenebrionidae). Journal of the New York Entomological Society 108 (1-2), p. 13-25.

Flores G.E. (2004) - Systematic revision and cladistic analysis of the Patagonian genus Platesthes (Coleoptera: Tenebrionidae). European Journal of Entomology 101 (4), p. 591-608.

Flores G.E. \& Pizarro-Araya J. (2004) Caenocrypticoides triplehorni new species, the first record of Caenocrypticini (Coleoptera: Tenebrionidae) in Argentina, with cladistic analysis of the genus. Annales Zoologici 54 (4), p. 721-728

GolobofF P.A. (1995) - A revision of the south American spiders of the family Nemesiidae (Araneae, Mygalomorphae) Part I: species from Peru, Chile, Argentina, and Uruguay. Bulletin of the American Museum of Natural History 224, p. 1-189.

Hartley A.J. (2003) - Andean uplift and climate change. Journal of the Geological Society 160 (1), p. 7-10. 
Morrone J.J. \& CRISCI, J.V. (1995) - Historical bio geography: introduction to methods. Annual Review of Ecology and Systematics 26, p. 373-401.

PeÑa L.E. (1966) - Catálogo de los Tenebrionidae (Coleoptera) de Chile. Entomologische Arbeiten aus dem Museum Georg Frey 17, p. 397-453.

Pizarro-Araya J. \& Jerez V. (2004) - Distribución geográfica del género Gyriosomus GuérinMéneville, 1834 (Coleoptera: Tenebrionidae): una aproximación biogeográfica. Revista Chilena de Historia Natural 77 (3), p. 491-500.

RoIG-JUÑENT S. (1995) - Cladistic analysis of Barypus Dejean 1828 (Coleoptera: Carabidae: Broscini). American Museum Novitates 3117, p. 1-11.

Roig-JuñEnt S. (2002) - Nuevas especies de Cnemalobus Guérin-Ménéville (Coleoptera, Carabidae) y consideraciones filogenéticas y biogeográficas sobre el género. Revista de la Sociedad Entomológica Argentina 61 (3-4), p. 51-72.
Roig-Juñent S. \& Flores G.E. (2001) - Historia bio geográfica de las áreas áridas de América del Sur austral. In: Llorente Bousquets J. \& Morrone J.J. (eds.), Introducción a la Biogeografía en Latinoamérica: Teorías, conceptos, métodos y aplicaciones, pp. 257-266. Las Prensas de Ciencias, Facultad de Ciencias, UNAM, México, D.F.

Roig-Juñent S., Flores G.E. \& MAtToni C.I. (2003) - Consideraciones biogeográficas de la Precordillera (Argentina), con base en artrópodos epígeos. In: Morrone J.J. \& Llorente Bousquets J. (eds.), Una perspectiva latinoamericana de la Biogeografía, pp. 275-288. Las Prensas de Ciencias, Facultad de Ciencias, UNAM, México, D.F. 


\begin{tabular}{|c|c|c|}
\hline Tribe & Genera & $\mathrm{N}^{\circ}$ species and distribution \\
\hline \multirow[t]{2}{*}{ Asidini } & Cardigenius & $9 \mathrm{spp}$ endemic to east of the Andes (Argentina, Brazil, Uruguay) \\
\hline & Scotinus & 10 spp endemic to east of the Andes (Brazil) \\
\hline \multirow[t]{2}{*}{ Caenocrypticini } & Caenocrypticoides & 1 sp endemic to east of the Andes (Argentina) \\
\hline & & 4 spp endemic to west of the Andes (Chile, Peru) \\
\hline Cnemeplatiini & Lepidocnemeplatia & 3 spp endemic to east of the Andes (Argentina, Bolivia, Brazil) \\
\hline Elenophorini & Megelenophorus & $1 \mathrm{sp}$ endemic to east of the Andes (Argentina, Bolivia) \\
\hline \multirow[t]{16}{*}{ Epitragini } & Aspidolobus & 3 spp endemic to west of the Andes (Chile) \\
\hline & Epitragella & $1 \mathrm{sp}$ endemic to east of the Andes (Argentina) \\
\hline & Epitragopsis & 1 sp endemic to west of the Andes (Chile) \\
\hline & & 2 spp endemic to east of the Andes (Argentina, Bolivia) \\
\hline & Epitragus & $4 \mathrm{spp}$ endemic to east of the Andes (Argentina, Paraguay) \\
\hline & Eunotioides & $3 \mathrm{spp}$ endemic to east of the Andes (Argentina, Bolivia, Paraguay) \\
\hline & Geoborus & 2 spp endemic to west of the Andes (Chile) \\
\hline & Hemasodes & $5 \mathrm{spp}$ endemic to east of the Andes (Argentina, Bolivia, Paraguay) \\
\hline & Hypselops & $1 \mathrm{sp}$ endemic to west of the Andes (Chile) \\
\hline & Nyctopetus & 4 spp endemic to east of the Andes (Patagonian steppes Argentina) \\
\hline & & $11 \mathrm{spp}$ endemic to west of the Andes (Chile) \\
\hline & Omopheres & $17 \mathrm{spp}$ endemic to east of the Andes (Argentina, Bolivia) \\
\hline & Parepitragus & $4 \mathrm{spp}$ endemic to west of the Andes (Chile, Peru, Ecuador) \\
\hline & Pectinepitragus & $1 \mathrm{sp}$ endemic to east of the Andes (Argentina) \\
\hline & Penaus & $1 \mathrm{sp}$ endemic to west of the Andes (Chile) \\
\hline & Pseudothinobatis & 2 spp endemic to west of the Andes (Chile) \\
\hline \multirow[t]{9}{*}{ Eurymetopini } & Achanius & $\begin{array}{l}6 \mathrm{spp} \text { inhabiting high altitudes in the Andes (Argentina, Bolivia, Peru) } \\
1 \mathrm{sp} \text { endemic to east of the Andes (Argentina) }\end{array}$ \\
\hline & Ambigatus & $1 \mathrm{sp}$ inhabiting high altitudes in the Andes (Peru) \\
\hline & & $4 \mathrm{sp}$ endemic to east of the Andes (Argentina) \\
\hline & & $1 \mathrm{sp}$ endemic to west of the Andes (Chile) \\
\hline & Arthroconus & $1 \mathrm{sp}$ endemic to east of the Andes (Argentina) \\
\hline & & 2 spp endemic to west of the Andes (Chile) \\
\hline & Hylithus & $1 \mathrm{sp}$ endemic to west of the Andes (Chile) \\
\hline & & 6 spp endemic to east of the Andes (Argentina) \\
\hline & & 6 spp inhabiting high altitudes in the Andes (Argentina, Bolivia, Chile, Peru) \\
\hline \multirow[t]{4}{*}{ Evaniosomini } & Aryenis & 2 spp endemic to west of the Andes (Chile, Peru) \\
\hline & & $1 \mathrm{sp}$ endemic to east of the Andes (Argentina) \\
\hline & & $1 \mathrm{sp}$ widely distributed on both sides of the Andes \\
\hline & Melaphorus & 2 spp endemic to west of the Andes (Chile, Peru) \\
\hline \multirow[t]{13}{*}{ Nycteliini } & Auladera & 4 spp endemic to west of the Andes (Chile) \\
\hline & Callyntra & $17 \mathrm{spp}$ endemic to west of the Andes (Chile) \\
\hline & Entomoderes & 9 spp endemic to east of the Andes (Argentina, Bolivia) \\
\hline & Epipedonota & $23 \mathrm{spp}$ endemic to east of the Andes (Argentina, Bolivia) \\
\hline & Gyriosomus & $38 \mathrm{spp}$ endemic to west of the Andes (Chile) \\
\hline & Mitragenius & $7 \mathrm{spp}$ endemic to east of the Andes (Argentina) \\
\hline & & $2 \mathrm{spp}$ endemic to west of the Andes (Chile) \\
\hline & Nyctelia & 2 spp endemic to west of the Andes (Chile) \\
\hline & & $\begin{array}{l}63 \text { spp endemic to east of the Andes (western Argentina and Patagonian } \\
\text { steppes Argentina, Chile) }\end{array}$ \\
\hline & Patagonogenius & $7 \mathrm{spp}$ endemic to east of the Andes (Patagonian steppes Argentina) \\
\hline & Pilobalia & $\begin{array}{l}46 \text { spp inhabiting high altitudes in the Andes (Argentina, Bolivia, Chile, } \\
\text { Peru) }\end{array}$ \\
\hline & Psectrascelis & $\begin{array}{l}74 \text { spp widely distributed on both sides of the Andes and inhabiting high } \\
\text { altitudes in the Andes (Argentina, Bolivia, Chile, Peru) }\end{array}$ \\
\hline & Scelidospecta & 5 spp endemic to east of the Andes (Argentina) \\
\hline Phrynocarenini & Phrynocarenum & $1 \mathrm{sp}$ endemic to east of the Andes (Argentina) \\
\hline \multirow[t]{5}{*}{ Physogasterini } & Entomochilus & 19 spp endemic to west of the Andes (Chile) \\
\hline & Philorea & 22 spp endemic to west of the Andes (Chile, Peru) \\
\hline & Physogaster & 8 spp endemic to west of the Andes (Chile) \\
\hline & & $3 \mathrm{spp}$ endemic to east of the Andes (Argentina) \\
\hline & & 4 spp inhabiting high altitudes in the Andes (Argentina, Chile) \\
\hline
\end{tabular}

TABL. 1 - List of tribes (Doyen, 1993) and genera (Peña, 1966, Flores, 1998) of Pimeliinae in Southern South America 


\begin{tabular}{|c|c|c|}
\hline \multirow{24}{*}{ Praocini } & Pimelosomus & 4 spp endemic to east of the Andes (Argentina, Bolivia) \\
\hline & Antofagapraocis & 2 spp inhabiting high altitudes in the Andes (Argentina, Bolivia, Chile) \\
\hline & Asidelia & $1 \mathrm{sp}$ endemic to east of the Andes (Argentina) \\
\hline & Calymmophorus & 5 spp endemic to east of the Andes (Argentina) \\
\hline & Eutelocera & $1 \mathrm{sp}$ endemic to east of the Andes (Argentina) \\
\hline & Falsopraocis & 3 spp inhabiting high altitudes in the Andes (Argentina, Chile) \\
\hline & Neopraocis & $1 \mathrm{sp}$ endemic to east of the Andes (Patagonian steppes Argentina, Chile) \\
\hline & Afrasida (Gyrasida) & $1 \mathrm{sp}$ endemic to west of the Andes (Chile) \\
\hline & Platesthes & $\begin{array}{l}12 \text { spp endemic to east of the Andes (Patagonian steppes Argentina, Chile) } \\
1 \text { sp endemic to west of the Andes (Chile) }\end{array}$ \\
\hline & Platyholmus & 16 spp endemic to east of the Andes (Argentina, Bolivia, Peru) \\
\hline & Praocis (Praocis) & $18 \mathrm{spp}$ endemic to west of the Andes (Chile) \\
\hline & Praocis (Mesopraocis) & $4 \mathrm{spp}$ endemic to west of the Andes (Chile) \\
\hline & Praocis (Postpraocis) & 4 spp endemic to west of the Andes (Chile) \\
\hline & & 1 sp inhabiting high altitudes in the Andes (northwestern Argentina) \\
\hline & Praocis (Anthrasomus) & 4 spp endemic to west of the Andes (Chile) \\
\hline & Praocis (Filotarsus) & 6 spp endemic to west of the Andes (Chile) \\
\hline & & 8 spp inhabiting high altitudes in the Andes (Argentina, Bolivia, Chile, Peru) \\
\hline & Praocis (Parapraocis) & 3 spp inhabiting high altitudes in the Andes (Peru) \\
\hline & Praocis (Hemipraocis) & 7 spp endemic to east of the Andes (Patagonian steppes Argentina, Chile) \\
\hline & Praocis (Praonoda) & 2 spp endemic to east of the Andes (Patagonian steppes Argentina, Chile) \\
\hline & Praocis (Orthogonoderus) & $\begin{array}{l}21 \text { spp widely distributed on both sides of the Andes and inhabiting high } \\
\text { altitudes in the Andes (Argentina, Bolivia, Chile, Peru) }\end{array}$ \\
\hline & Praocis (Praocida) & $1 \mathrm{sp}$ endemic to east of the Andes (Argentina) \\
\hline & & 3 spp inhabiting high altitudes in the Andes (Argentina, Bolivia, Peru) \\
\hline & Thylacoderes & $4 \mathrm{spp}$ endemic to east of the Andes (Argentina) \\
\hline Psammetichini & Psammetichus & 13 spp endemic to west of the Andes (Chile, Peru) \\
\hline \multirow[t]{6}{*}{ Stenosini } & Discopleurus & 4 spp endemic to west of the Andes (Chile, Peru) \\
\hline & & $1 \mathrm{sp}$ endemic to east of the Andes (Argentina) \\
\hline & Ecnomoderes & 2 spp endemic to east of the Andes (Argentina) \\
\hline & Grammicus & $1 \mathrm{sp}$ endemic to west of the Andes (Chile, Peru) \\
\hline & Hexagonochilus & 2 spp endemic to west of the Andes (Chile, Peru) \\
\hline & Schizaraeus & $1 \mathrm{sp}$ endemic to east of the Andes (Argentina) \\
\hline \multirow[t]{2}{*}{ Thinobatini } & Cordibates & $7 \mathrm{sp}$ endemic to west of the Andes (Chile) \\
\hline & Thinobatis & $13 \mathrm{spp}$ endemic to west of the Andes (Chile) \\
\hline \multirow[t]{7}{*}{ Trilobocarini } & Derosalax & $1 \mathrm{spp}$ endemic to east of the Andes (Argentina) \\
\hline & Eremoecus & 2 spp endemic to west of the Andes (Chile) \\
\hline & Peltolobus & 2 spp endemic to west of the Andes (Chile) \\
\hline & & 3 spp endemic to east of the Andes (Patagonian steppes Argentina, Chile) \\
\hline & Salax & $1 \mathrm{sp}$ distributed on both sides of the Andes \\
\hline & Trilobocara & 2 spp endemic to east of the Andes (Argentina) \\
\hline & & $1 \mathrm{sp}$ endemic to west of the Andes (Chile) \\
\hline Total species & & 669 \\
\hline
\end{tabular}

TABL. 1 (suite) - List of tribes (Doyen, 1993) and genera (Peña, 1966, Flores, 1998) of Pimeliinae in Southern South America 